\title{
Cosmopolitan Civility:
}

\section{understanding power and difference}

The 4 Rs conference at the University of Technology Sydney in October 2008 took place less than a year after the election of the Rudd Labor government. The moment is important to capture - the government had been swept into office on a wave of hostility to the Howard conservatives, but it did not have a mandate for radical reform. Its promises had carefully targeted key constituencies - skilled workers, small business, the urban "chattering” classes, people in education, in health and in the arts (to a small extent). The government was committed to fiscal discipline with a more humane face, its great vision summarised under the rubric of "social inclusion".

Already at the 300 day mark after the election (a major keynote panel at the Conference with Sharron Burrow, Robert Manne and Laurie Ferguson carried that reference http://www.themonthly.com.au/taxonomy/term/84?page=5), there was growing unease about the pace and direction of reform. Despite the Apology to the Stolen Generation, the Intervention in the Northern Territory continued, with little to show except articulate and angry Indigenous spokespeople. The three hundred participants in the 4rs Conference engaged with many of these issues, from indigenous rights to legal protest in the P R China, from social inclusion to racism, from the environmental crisis to feminism in Islam.

The articles that we have included in this issue of the Cosmopolitan Civil Societies eJournal have been chosen to reflect the diversity of the conference, its themes and the debate that took place there. The eight pieces traverse the space from the legality of the establishment of the colonies in Australia, the attempts to reconcile Australians of Indigenous and nonIndigenous heritage, through the building of social capital in localities, to educational strategies in diverse communities, to democratic opportunities in the largest country in the world. There is a meta-narrative that we can extract from these papers, an understanding more or less clearly articulated that social cohesion requires ultimately a recognitional politics, where power and difference face each other and decide to reach an accommodation based on civility.

Francesca Dominello opens this conversation in her discussion from a socio-legal perspective of the underpinnings of European colonisation of Australia. She argues that, through the Mabo case, Indigenous people from the Torres Strait challenged the taken-for-granted jurisprudence of Australia that had underpinned White hegemony for two centuries. She notes that Mabo broke a deadlock, by opening up the possibility of legal equality from a position of difference, rather than uniformity. Yet the case may have produced only a shortterm outcome that conservative and homogenising forces have sought to suppress, or have reinterpreted in ways that reinforce their material, political and ideological interests.

Andrew Gunstone then addresses the legacy of the story that Mabo has drawn from the shadows, the tensions implicit in the whole discourse of Reconciliation. He points to the failure of the greatly-touted Reconciliation process, from its emergence as an alternative to effective land rights, and as a disguise for the real struggles over power and selfdetermination that occurred in the backstage of Australian political theatre for the decade of Reconciliation. 
Nahid Kabir focuses our attention on a contemporary manifestation of the politics of recognition, that moment of intergenerational complexity where adolescent young Australian women of Muslim faith try to build an identity that balances the competing forces they experience - from parents and home, religious authorities, school and peer-group. Kabir argues that the girls perform according to different scripts at home with family and in religious environments, compared to their immersion in school and peer networks. These tensions, she argues, can fragment the fragile personal identity of the young person, leaving her open to quite severe emotional distress. In order to protect them somewhat Kabir argues for a greater social involvement in these issues, through a social movement model.

Nina Burridge and her colleagues explore the way in which schools respond to the presence of the newcomers. They critically review how "multiculturalism” is operationalised, arguing that schools take very different perspectives on diversity, depending on their local communities. Policy may promote educational strategies of diversity but the school responds in part through how executives manage their relations with their surrounding populations. Should policy be more pro-active, building capacity to ensure students are more cosmopolitan in their social capacities?

The interface between the individual and the group, between primary and secondary associations, and between long-established "locals" and newly settled arrivals, forms the basis for Rob Garbutt's testing of the concept of social inclusion. The inclusion/exclusion nexus is not solely about formal group membership, but rather is an everyday experiential issue, played out in the relations that people have with each other, the active sense of belonging (or not) that underpins the drier policy concepts. Garbutt uses critical language theory to reflect on the meanings of being "local" as they are expressed in media about Lismore and Cronulla. He shows how in Lismore the boundaries are directed in two directions - towards Aborigines and at hippies, while in Cronulla the language draws a line between "Australians" and people from the Middle East. He then looks at a number of local projects designed to bridge such barriers through shared telling of personal narratives of survival.

Personal and communal engagement requires institutional forms, Susan McClean and Jenny Onyx argue in their exploration of community housing options in Adelaide. The Third Way - between the rampant inequities of the capitalist market and the bureaucratic strictures of state provision - could provide a solution for affordable housing provision. Eco-cities address issues of both environmental and social sustainability, even though they face enormous barriers from both the state and the market. Christie Walk, an Adelaide ecocommunity, has developed through the socio-political commitment of its participants, and mobilisation of their social capital to hold this communal collaboration together.

Is the individual or even small-group communal focus sufficient to engage with climate change and the necessary changes in social arrangements that environmental crisis demands of contemporary citizens? Jennifer Kent argues that the individualisation of climate change responsibilities that typify neo-liberal government mobilisation strategies seriously harm the capacity of society to cope with the changes afoot. Rather there needs to be a concerted effort focussed on citizen-action initiatives, even though these are not in favour with governments. Behavioural change requires societal infra-structural change, without which the individual will be swamped by the environmental challenges that really exist behind the rhetoric. 
Sometimes though the societal challenges appear just too huge, the entrenched resistance of the state too embedded, the vested interests too powerful. Feng Chongyi tackles exactly this problem in his examination of the rise of defence lawyers in the Peoples' Republic of China. He shows how discourses of human rights have flourished as China's modernisation progresses, even through the painful repression around Tiananmen and the attacks on democratic activists. Feng proposes that the concept of rights has become more widely accepted in China, accelerated both by local protests against oppressive or corrupt government actions, and by a rising stratum of legal representatives willing to defend the interests of those being oppressed. While the state controls traditional media, the Internet has become a flourishing site for the communication of rights and the celebration of small victories.

We can talk then quite usefully of the widespread value of the notion of cosmopolitan civility. It rests on a theoretical engagement with the politics of recognition and reciprocity, and a practical scholarly commitment to the use of knowledge for social change. The rise of the discourse of social inclusion, promoted by the Australian government as the basis of its "attack" on social disadvantage, has placed many of these questions at the heart of debates about social policy.

Two major questions are revealed by the sorts of arguments that this issue of the journal covers. The first must be the relation between social inclusion and social inequality and whether the rubric of social inclusion requires significant changes in the levels of social inequality, which have grown in Australia over recent decades. Concern for marginalisation is not the same as concern for equity - the former is about social control and cohesion, that latter addresses the far more complex issues of social justice and the unequal distribution of power.

The second question reflects the silence in much of government rhetoric about cultural diversity - either in relation to Indigenous people or to ethnic and refugee communities. Social inclusion has political, cultural, social and economic dimensions, even in its most limited and conservative reading. As yet there are few signs that the diversity dimensions have gained any purchase on the public debate and the direction of government policy priorities.

We welcome your feedback and commentary on the articles, and the ongoing participation of our readership in forming the directions for the CCS eJournal. 